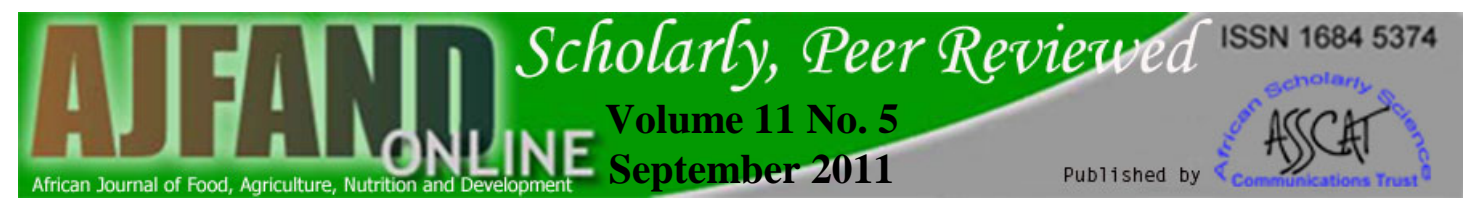

\title{
EFFECT OF RIPENING STAGE ON COMPOSITION, SENSORY QUALITIES AND ACCEPTABILITY OF KEITT MANGO (MANGIFERA INDICA L.) CHIPS
}

$$
\text { Appiah } \mathbf{F}^{1 *} \text {, Kumah } \mathbf{P}^{1} \text {, and I Idun }{ }^{1}
$$

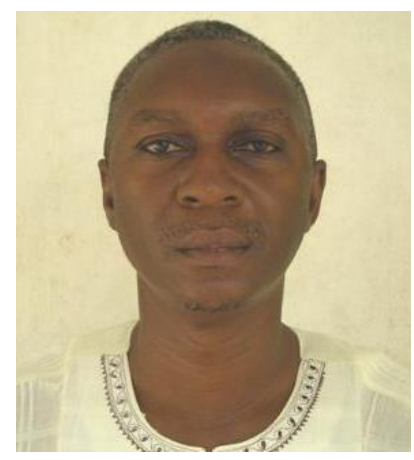

Francis Appiah

*Corresponding author’s email: fappiah_sp@yahoo.com OR fappiah.sp@gmail.com

${ }^{1}$ Department of Horticulture, Faculty of Agriculture, College of Agriculture and Natural Resources, Kwame Nkrumah University of Science and Technology, Kumasi, Ghana. 


\begin{abstract}
Mango (Mangifera indica) fruits are consumed, among other reasons, for their pleasant flavour. They are rich sources of vitamins $A, B_{6}$ and C. Mango fruits are being increasingly processed into products such as dried mango slices (chips). These products have longer shelflife and, therefore, assure all year round availability of mango in different forms. The stage of ripening of mango fruits influences consumer acceptability. This is because it affects the physico-chemical characteristics of the mango fruit. In order to produce mango chips of acceptable quality, determination of the most appropriate stage of ripening of fruits for chip production should be known. This study was, therefore, carried out to determine the effect of stage of ripening of Keitt mango fruits on eating quality of its derivative chips. Some physicochemical changes occurring in fruits were monitored during ripening. The results showed that there were significant increases $(\mathrm{P}<0.05)$ in total soluble solids and $\mathrm{pH}$ while titratable acidity and vitamin $\mathrm{C}$ content declined with ripening. No significant differences were observed between the different stages of ripening in any of the proximate parameters with the exception of the ash content. Chips showed increased levels of ash with ripening. Magnesium levels in chips increased with ripening whereas the levels of phosphorus, potassium, calcium and sodium declined. Sensory evaluation of the chips revealed that chips produced from fully ripe Keitt mango fruits were more acceptable than half ripe and unripe mango fruits. The chips from the fully ripened had the best scores for appearance (1.37), taste (1.27), flavour (1.38) as well as mouthfeel (1.45). The texture of chips produced using the fully ripened Keittt mango fruits were adjudged to be satisfactory (2.64). The study showed that fully ripened mango fruits were better in producing chips of acceptable sensory quality than both unripe and fullripe mango fruits. The taste which was mainly due to the sugar content of the mango chips contributed significantly to overall acceptability and therefore could be used as a quality indicator of Keitt mango chips.
\end{abstract}

Key words: Mango, physico-chemical, sensory, quality, chips 


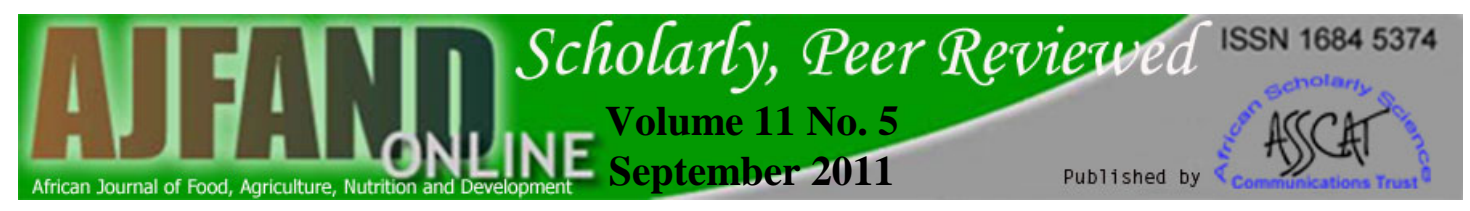

\section{INTRODUCTION}

Mango (Mangifera indica L.), a fruit native to the tropics and sub-tropics belongs to the family Anacardiaceae [1] and is usually consumed for its pleasant taste and flavour [2]. It is a rich source of vitamins $\mathrm{A}$ and $\mathrm{C}$ as well as dietary fibre.

Mangoes make up 50\% of all tropical fruits produced worldwide. Global production of mangoes was estimated to be 35.04 million tonnes in 2009. India was the leading producer with 13.65 million tonnes in 2008 [3]. In 2005, the world's export of mango reached 912,853 metric tonnes and was worth US\$543.10 million [4]. In spite of these economic indicators, mango is a delicate and highly perishable fruit and is therefore processed to ensure all year round availability in different forms [5]. The production of novel products from mango can increase the value of mango. Mango is utilized for the processing of juice, nectars, fruit leather, and frozen pulp as well as a flavouring product for baked foods, ice cream and yoghurt [6]. Dried pieces may be added to salads and fruit cocktail. The most popular export mango cultivars include Kent, Haden, Tommy Atkins and Keitt [7].

The quality of processed mango depends on many factors including quality of fruit at harvest. Though mango fruits are much appreciated when harvested after full ripening, harvesting at the half-ripe stage is generally recommended. The importance of the stage of ripening at harvest is critical as notable changes occur in the fruit during ripening.

Dried mango pulps are among important mango products with great potential in addressing food security and nutrition concerns around the world. Mango at various stages of ripening can be dried and consumed. This study therefore sought to assess the effect of stage of ripening on the eating quality of dried mango pulp produced as chips.

\section{MATERIALS AND METHODS}

\section{Sample Collection}

Fully mature Keitt mango fruits were harvested from Dormehsco Farm at Somanya in the Eastern Region of Ghana and transported to the laboratory of the Department of Horticulture, Faculty of Agriculture, KNUST, Kumasi, Ghana for analysis.

\section{Sample preparation}

One hundred and eighty fruits were selected from mature mango fruits plucked from the same tree for the study. Selected fruits were uniform and undamaged with no visible symptoms of infection. Fruits were cleaned and randomly grouped into 3 groups (60 mangoes per group). Each group was subdivided into 3 subgroups (replicates) with each subgroup having 20 fruits. Fruits were allowed to ripen under room conditions $\left(30-33^{\circ} \mathrm{C}\right)$. The first group (60 fruits) were analysed unripe, the second analysed half-ripe while the third was analysed fully-ripe. The procedure for determining the stage of ripening of mango fruits was used with slight modification [8]. Fruits were considered unripe when firm with no depression when thumbpressed. Fully ripe fruits had strong perfume, and indented upon pressing with the thumb while half-ripe indented slightly. Five mango fruits per replicate of 20 were used for the analyses and another 10 used for chip production. This procedure was repeated for all

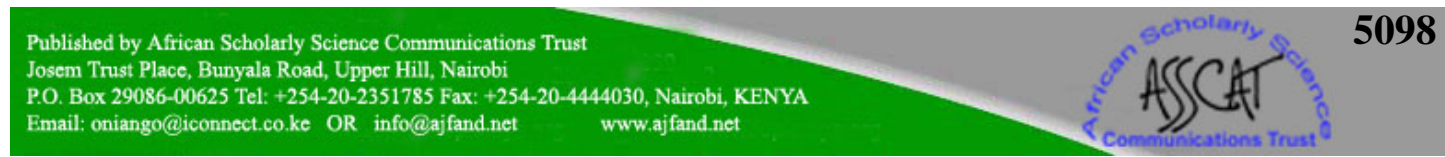


treatments.

\section{Chips production}

Keitt mango fruits were washed, peeled and sliced into slices $(2 \mathrm{~cm} \times 4 \mathrm{~cm} \times 0.5 \mathrm{~cm})$ and spread evenly on trays lined with aluminum foil. Trays were then placed in a Wagtech oven (Model GP120SSE300HYD, Wagtech International Ltd, USA) at a temperature of $40^{\circ} \mathrm{C}$ for 18 hours. The slices were turned every 2 hours to ensure uniform drying. The dried slices were allowed to cool for about 30 minutes in a dessicator prior to analysis [9].

\section{Chemical Analysis}

Standard procedures of the AOAC were used for proximate determinations, $\mathrm{pH}$, total soluble solids, titratable acidity, Vitamin $\mathrm{C}$ and mineral content [10]. $\mathrm{pH}$ was measured using a Suntex electronic pH meter (model FF 701, Suntex Instuments Co. Ltd, USA). Total soluble solids was determined with a Bellingham and Stanley Delta hand refractometer. Potassium and sodium were determined by flame emission photometry (Jenway PFP-7, Jenway Ltd, England), calcium and magnesium by EDTA complexometric titration while phosphorus was determined by Ammonium Molybdate method.

\section{Sensory evaluation}

Sensory evaluation was carried out on the chips using 15 trained panelists. Sensory attributes assessed were appearance, taste, aroma, crispness, mouthfeel and overall acceptability. A hedonic scale of 1-5 (1 - Like very much; 2 - Like slightly; 3 - Neither like nor dislike; 4 Dislike slightly; 5 - Dislike very much) was used for the assessment [11].

\section{Data analysis}

Analysis of variance was carried out using GENSTAT (Discovery edition 3). Least significant difference (LSD) test was used to determine differences between means.

\section{RESULTS}

\section{Physico-chemical characteristics of mango fruits at $\mathbf{3}$ stages of ripeness}

Table 1 shows some chemical changes in the pulps of Keitt mango fruits (used for mango chip production) during ripening. Moisture content of the fruits increased significantly $(\mathrm{P}<0.01)$ during ripening from $79.75 \%$ to $83.11 \%$ and correlated positively with both taste $(\mathrm{R}=0.94)$ and aroma $(\mathrm{R}=0.97)$ of chips. Similarly, total soluble solids content increased significantly $(\mathrm{P}<0.01)$ in the mango pulp from $7.00 \%$ to $15.95 \%$. As regards the $\mathrm{pH}$, ripening resulted in significant increase from 2.47 to 3.90. There was a significant $(\mathrm{p}<0.01)$ decrease in Vitamin C content from $29.08 \mathrm{mg} / 100 \mathrm{~g}$ to $3.45 \mathrm{mg} / 100 \mathrm{~g}$. Titratable acidity content in the mango fruits showed significant decline $(\mathrm{P}<0.01)$ with ripening.

\section{Nutritional composition of chips}

As indicated in Table 2, the moisture content of the chips produced showed marginal but insignificant increase with ripening from $8.74 \%$ to $11.43 \%$. Changes in crude protein, crude fibre and carbohydrates of chips were not significant $(\mathrm{P}>0.01)$. However, significant increase in ash content was observed. The ash content of the chips produced using mangoes at different stages of ripening showed an increase from 5.80\% to $8.58 \%$ with ripening. Mango chips produced using ripe mangoes showed significantly higher magnesium content

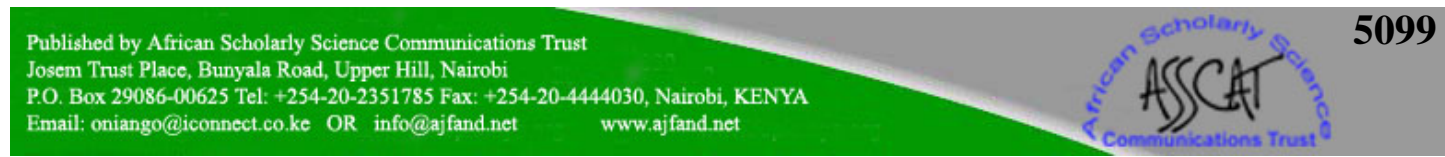


(0.624mg/100g) 1.63 times that of chips produced from unripe mangoes. Phosphorus content of the mango chips ranged between $0.09 \mathrm{mg} / 100 \mathrm{~g}$ and $0.13 \mathrm{mg} / 100 \mathrm{~g}$ showing a marginal decrease as indicated in Table 3. Similarly, there were insignificant decreases in potassium (0.78 to $0.67 \mathrm{mg} / 100 \mathrm{~g}$ ), calcium (0.48 to $0.32 \mathrm{mg} / 100 \mathrm{~g}$ ) and sodium (0.66 to $0.56 \mathrm{mg} / 100 \mathrm{~g}$ ).

\section{Sensory evaluation of mango chips}

Table 4 shows sensory scoring for mango chips by the sensory panel. Crispness of the chips produced from unripe fruits was the most preferred (1.72) followed by half ripe (2.29) and then full ripe (2.64). The difference in crispness between the various stages of ripening were significant $(\mathrm{P}<0.05)$. There was a strong inverse association $(\mathrm{r}=-0.99)$ between crispness and total soluble solids.

The taste of the chips was significantly affected by the stage of ripening of the fruits used for producing the chips. The taste of chips produced from the full-ripe mango fruits was preferred (1.27) compared to both the unripe (2.91) and half-ripe (2.52). However, the preference for the chips produced using half-ripe fruits was not significantly different from the full ripe. A strong positive correlation was found between taste and total soluble solids $(\mathrm{r}=0.96)$ as well as taste and $\mathrm{pH}(\mathrm{r}=0.98)$. However, taste correlated inversely $(\mathrm{r}=-0.98)$ with titratable acidity.

The aroma of chips produced from the full-ripe mangoes was the most preferred (1.38) followed by half-ripe (2.41) and unripe (2.89).

The appearance of the chips produced from mangoes produced using mangoes at different stages of ripening differed significantly from each other. Chips produced from full-ripe mango fruits were the most preferred (1.37) as compared to those from the half-ripe (2.33) and unripe (2.61) mangoes.

The results of the study indicated that chips produced using full-ripe mangoes gave the most preferred mouthfeel with a score of 1.45 . This was followed by half-ripe (2.49). The chips from the unripe mangoes were the least preferred. There were strong positive correlations $(\mathrm{R}=0.99)$ between both mouthfeel and total soluble solids as well as mouthfeel and titratable acidity.

Mean scores for overall acceptability for the chips were 3.13, 2.56 and 1.38 for unripe, halfripe and full-ripe respectively. Differences in overall acceptability of mango chips produced from the unripe and half-ripe mangoes were not significant $(\mathrm{P}<0.05)$. However, differences between unripe and full-ripe as well as half-ripe and full-ripe were significant. Regression analysis showed significant coefficient of regression $\left(\mathrm{R}^{2}=0.36 ; \mathrm{P}=0.0004\right)$ for taste. Regression analysis showed that the contribution of taste to overall acceptability was governed by the equation ' $y=0.823+0.5385$ (taste)'

\section{DISCUSSION}

\section{Changes in Moisture, pH, TA, TSS and vitamin $\mathrm{C}$ during ripening of fruits}

Table 1 shows some chemical changes in Keitt mango fruits during ripening. The increase in moisture content of the fruits during ripening could be attributed to loss of moisture from the

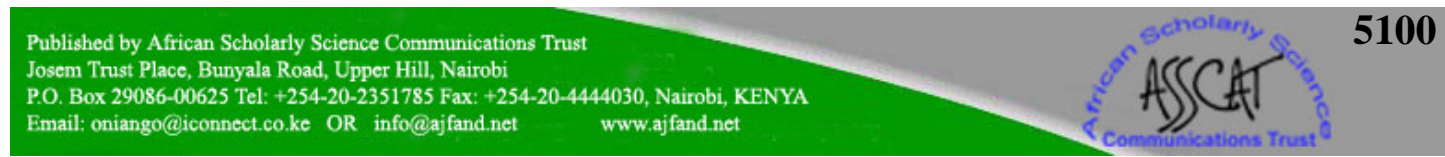


peel to the pulp. During ripening, carbohydrates are hydrolysed into sugars increasing osmotic transfer of moisture from peel to pulp [12]. The observed increase in moisture content of the mango pulp was therefore expected. Water is an important solvent for many soluble substances such as salts, sugars that are known to influence taste in fruits. The increase in moisture content of the fruit pulps during ripening therefore could have enhanced the taste and aroma of the fruits as shown by the strong positive correlations between moisture content (fruit pulps and mango chips) and taste as well as aroma of chips.

Soluble sugars of mango pulps are mainly composed of fructose, with about 30\% sucrose and $20 \%$ glucose [13]. Similarly, sucrose has been reported to be the major sugar in mango [14]. Significant increase in sucrose content of mango has been observed during ripening and this has been attributed to an increase in total soluble solids during ripening. This is due to transformation of starch into soluble sugars as the carbohydrates in the fruit are broken down under the action of phosphorylase enzyme during ripening into simple sugars $[15,16]$. On the other hand, hydrolysis of starch in the ripening mango fruit has been associated with amylase activity [17]. The increase in total soluble solids during ripening was expected and this suggests the extent of sweetening [18]. The effect of increased total soluble solids was observed in the taste of chips produced as it correlated positively with taste.

Similarly, a decrease in titratable acidity of mango fruits during ripening has been reported [15]. Titratable acidity gives a measure of the amount of acid present in a fruit [19]. Citric acid is known to be the major acid in mango [11]. The decline in acidity could be due to susceptibility of citric acid to oxidative destruction as impacted by the ripening environment [20]. The decreases in acidity suggest reduction in sourness with the potential of improving the sweet taste as was observed in chips produced in this study (Table 5). The decline in acidity during ripening is a consequence of starch hydrolysis leading to an increase in total sugars and a reduction in acidity[17].

Increase in $\mathrm{pH}$ during ripening of mango fruits has been reported by other authors [21] and was similar to what was observed in the present study ]. According to the authors, there is an inverse relationship between titratable acidity and $\mathrm{pH}$. The increase in $\mathrm{pH}$ (decline in acidity) could be due to utilisation of acids as respiration substrates [19].

The observed decrease in Vitamin C content of the mango fruits during ripening is of concern as it is an important vitamin for both consumer health [22] and chips stability during storage [23]. A similar trend has been observed by other authors during ripening of different mango varieties [8]. This decrease is attributable to susceptibility of Vitamin $C$ to oxidative destruction during ripening [20]. The reduction in Vitamin $C$ content during ripening coupled with heat treatment (oven drying during chip production) suggests that the chips would need to be fortified with Vitamin C to meet the US daily reference intake of 75 and $90 \mathrm{mg} /$ day for women and men, respectively [23].

\section{Nutritional composition of mango chips}

Similarly, an increase has been observed in the ash content during ripening of banana [24]. The high ash content of the chips suggests Keitt mango chips could be rich in minerals as was observed in this study [25]. The high carbohydrate content of the chips suggests they could be very good sources of energy. Since the mango chips had high mineral content, they could be a

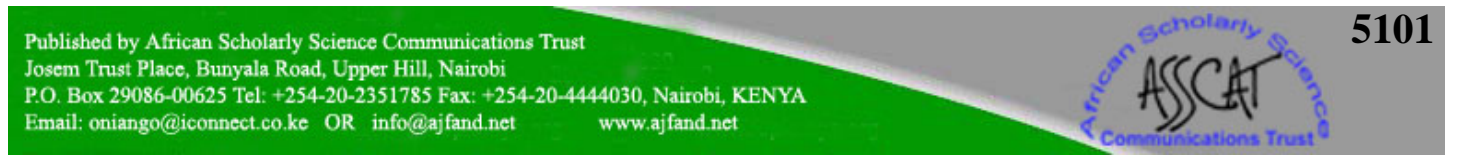


useful source of minerals. As regards the effect of stage of ripening on mineral content, the observed decreases in phosphorus, calcium, and sodium content suggests that chips produced from fully ripe mangoes would supply less of the minerals. Since the chips produced using full ripe mangoes had lower levels of sodium, they could be consumed without much apprehension about excessive sodium intake. On the other hand, the increase in magnesium with ripening indicates that chips from full ripe mangoes could supply part of the magnesium requirement in humans. Magnesium has been reported to be essential in enzyme systems and helps maintain electrical potential in nerves [26]. Considering the daily requirement of magnesium of $400 \mathrm{mg} / \mathrm{day}$ for an adult, consuming $100 \mathrm{~g}$ of the ripe mango chips would be sufficient to provide the daily magnesium needs of an adult human [27].

\section{Sensory evaluation of mango chips}

The preference for the crispness of the chips produced using unripe mango fruits was probably due to their brittleness. Ripening is known to induce physico-chemical changes such as softening in fruits. Unlike the chips from the ripe mangoes which were soft and elastic, those from the unripe mangoes were crispy. The declining acceptance of crispness with ripening could be attributed to the softening of the pulp, high moisture as well as high total soluble solids content at full ripeness. It was observed that the chips from the ripe fruits were softer and more elastic instead of brittle. It is known that an increase in total soluble solids in fruits is closely associated with ripening which is usually accompanied by softening. This explains why the chips with higher total soluble solids recorded the lowest crispness. Crispness correlated inversely ( $\mathrm{r}=-0.99)$ with total soluble solids. Since there was significant difference between chips produced using half-ripe and full ripe mangoes it suggests that both gave similar degree of crispness.

There were significant differences in taste of chips produced from the three ripening stages $(\mathrm{p}<0.05)$. Taste of chips produced from the full-ripe mango fruits was most preferred (1.27) compared to both the unripe (2.91) and half-ripe (2.52) which had similar taste. Full-ripe chips performed better probably due to their reduced acidity and increased total soluble solids (sweetness) since there was a strong positive correlation $(\mathrm{r}=0.96)$ between taste to total soluble solids as well as taste and $\mathrm{pH}(\mathrm{r}=0.98)$. However, there was an inverse relationship $(r=-0.98)$ with titratable acidity. From the observation, it could be inferred that the taste of the mango chips was closely related to their sweetness and acidity as has been reported [28]. Taste improved with increasing sweetness and decreasing acidity. This explains why the ripe chips were preferred. However, as far as taste was concerned, half-ripe was as good as fullripe. Acids are known to be responsible for the taste in most fruits with low $\mathrm{pH}$. As starch in fruits is transformed into sugars during ripening, the taste becomes sweet due to increased sugar levels contributing to the taste of the fruit.

The panelists however, did not like the taste of chips made from the unripe fruits due to their sourness (acidic).

The aroma of fruits improves during ripening and this explains why the aroma of chips produced from the full-ripe mango fruits was preferred to the others by the panelists [29]. The characteristic aroma of fruits is usually derived from the production of different volatile compounds. Mono- and sesqui-terpene hydrocarbons are known to be the major aroma compounds in mango [30].

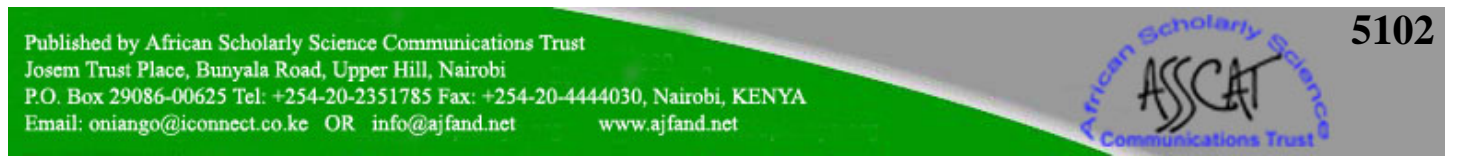


Chips produced from full-ripe mango fruits scored highest for appearance (1.37) as compared to those from the unripe (2.61) and half-ripe mangoes (2.33). During ripening, the intensity of yellowing increased in the mango fruit. This might have contributed to the attractiveness of full-ripe chips. There were significant differences observed in the appearance between the different chips produced from the green-mature, half-ripe and full-ripe mango fruits.

Mouthfeel is an indicator of the sensation of food in the mouth. The results of the study indicated that chips produced using full-ripe mangoes gave the most preferred mouthfeel. This was followed by half-ripe with unripe being the least preferred. It could be deduced that the total soluble solids content and acidity were important quality parameters that influenced the perception of mouthfeel by the sensory panel. Preference for the mouth sensation given by the full-ripe chips could be attributed to their high sugar content and titratable acidity of their pulps since total soluble solids correlated positively to mouthfeel $(\mathrm{r}=-0.99)$ and inversely to titratable acidity ( $\mathrm{r}=-0.99)$.

The panelists generally preferred chips produced from the full-ripe Keitt mango fruits to those made from the mature-green mangoes or half-ripe mangoes. This was due to higher total soluble solids content. Regression analysis showed that the taste of the chips contributed significantly to the observed overall acceptability as indicated in the regression analysis. However, since only $36 \%$ of the variability was explained by taste, it suggests quality indicators other than those assessed were probably used by the sensory panel in deciding on overall acceptance. This

notwithstanding, taste could be used as an important determinant of acceptability of Keitt mango chips.

\section{CONCLUSION}

The study indicates that the stage of ripening of Keitt mango has chemical, nutritional as well as sensory implications on chips produced from it. Ripening resulted in a higher magnesium content of the chips but a decrease in phosphorus, calcium and sodium. With the exception of texture all the other sensory parameters monitored were most accepted for the chips produced using full-ripe mangoes. The results of this study have shown that full-ripe mangoes are better for producing mango chips and that taste is an important quality indicator for the acceptability of mango chips.

\section{ACKNOWLEDGEMENTS}

The authors thank the Department of Horticulture of the Faculty of Agriculture, Kwame Nkrumah University of Science and Technology, Kumasi, Ghana, for hosting the study. We also thank Dormehsco Farms for donating the mango fruits used for the study. The authors appreciate the sensory panel for their commitment without which this study would not have been possible. 


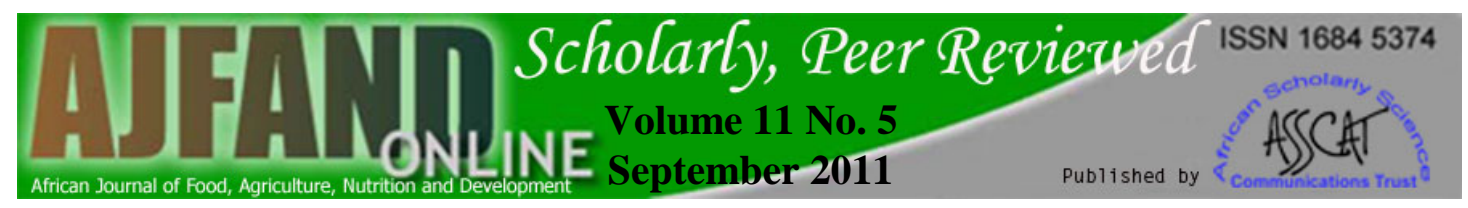

Table 1: Chemical changes in Keitt mango fruits during ripening

\begin{tabular}{cccccc}
\hline $\begin{array}{c}\text { Stage of } \\
\text { ripening }\end{array}$ & $\begin{array}{c}\text { Moisture } \\
(\%)\end{array}$ & $\begin{array}{c}\text { Total soluble } \\
\text { solids }\end{array}$ & $\begin{array}{c}\text { Titratable } \\
\text { acidity } \\
(\%)\end{array}$ & $\mathrm{pH}$ & $\begin{array}{c}\text { Vitamin C } \\
(\mathrm{mg} / 100 \mathrm{~g})\end{array}$ \\
\hline Unripe & $79.75 \pm 0.01$ & $7.00 \pm 0.04$ & $0.86 \pm 0.01$ & $2.47 \pm 0.01$ & $29.08 \pm 0.02$ \\
Half-ripe & $81.57 \pm 0.02$ & $11.50 \pm 0.03$ & $0.69 \pm 0.01$ & $3.06 \pm 0.02$ & $19.54 \pm 0.03$ \\
Full-ripe & $83.11 \pm 0.05$ & $15.95 \pm 0.03$ & $0.47 \pm 0.02$ & $3.90 \pm 0.04$ & $3.47 \pm 0.01$ \\
\hline Lsd (P=0.05) & 1.00 & 1.20 & 0.11 & 0.34 & 2.12 \\
\hline
\end{tabular}




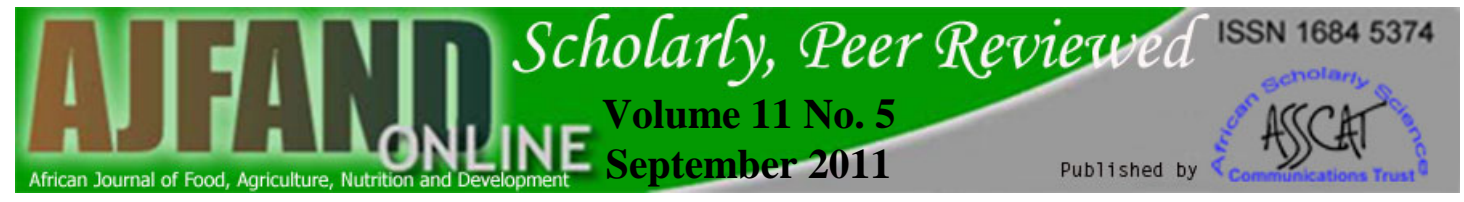

Table 2: Proximate composition of chips (\%)

\begin{tabular}{ccccccc}
\hline $\begin{array}{c}\text { Stage of fruit } \\
\text { ripening }\end{array}$ & Moisture & $\begin{array}{c}\text { Crude } \\
\text { Protein }\end{array}$ & Crude fat & $\begin{array}{c}\text { Crude } \\
\text { fibre }\end{array}$ & Ash & Carbohydrates \\
\hline Unripe & $8.74 \pm 0.01$ & $4.90 \pm 0.03$ & $0.09 \pm 0.02$ & $1.52 \pm 0.03$ & $5.80 \pm 0.02$ & $78.95 \pm 0.01$ \\
Half-ripe & $9.74 \pm 0.03$ & $4.46 \pm 0.05$ & $0.15 \pm 0.03$ & $1.73 \pm 0.03$ & $8.37 \pm 0.03$ & $75.55 \pm 0.07$ \\
Full-ripe & $11.43 \pm 0.05$ & $4.01 \pm 0.01$ & $0.27 \pm 0.02$ & $1.80 \pm 0.04$ & $8.58 \pm 0.06$ & $73.91 \pm 0.02$ \\
\hline Lsd $(\mathrm{P}=0.05)$ & 2.72 & 0.92 & 0.19 & 0.31 & 0.63 & 5.19 \\
\hline
\end{tabular}

Table 3: Mineral composition of Keitt mango chips (mg/100g)

\begin{tabular}{cccccc}
\hline Stage of fruit ripening & Phosphorus & Potassium & Calcium & Magnesium & Sodium \\
\hline Unripe & $0.13 \pm 0.01$ & $0.78 \pm 0.02$ & $0.48 \pm 0.02$ & $0.38 \pm 0.03$ & $0.66 \pm 0.02$ \\
Half-ripe & $0.12 \pm 0.01$ & $0.72 \pm 0.03$ & $0.48 \pm 0.04$ & $0.62 \pm 0.01$ & $0.64 \pm 0.01$ \\
Full-ripe & $0.09 \pm 0.03$ & $0.67 \pm 0.02$ & $0.32 \pm 0.06$ & $0.62 \pm 0.03$ & $0.56 \pm 0.01$ \\
\hline Lsd (P=0.05) & 0.02 & 0.18 & 0.10 & 0.03 & 0.08 \\
\hline
\end{tabular}


Table 4: Panelists scoring for sensory parameters of Keitt mango chips

\begin{tabular}{ccccccc}
\hline $\begin{array}{c}\text { Stage of fruit } \\
\text { ripening }\end{array}$ & Crispness & Taste & Aroma & Appearance & Mouthfeel & $\begin{array}{c}\text { Overall } \\
\text { acceptability }\end{array}$ \\
\hline Unripe & 1.72 & 2.91 & 2.89 & 2.67 & 3.09 & 3.13 \\
Half-ripe & 2.29 & 2.52 & 2.41 & 2.33 & 2.49 & 2.56 \\
Fully ripe & 2.64 & 1.27 & 1.38 & 1.37 & 1.45 & 1.38 \\
\hline Lsd (P=0.05) & 0.81 & 0.61 & 0.61 & 0.59 & 0.67 & 0.62 \\
\hline
\end{tabular}

Table 5: Correlation between chemical characteristics of Keitt mango fruits and sensory attributes of mango chips

\begin{tabular}{lllllll}
\hline Parameters Studied & Crispness & Taste & Aroma & Appearance & $\begin{array}{l}\text { Mouth } \\
\text { Feel }\end{array}$ & $\begin{array}{l}\text { Overall } \\
\text { Acceptability }\end{array}$ \\
\hline $\mathrm{pH}$ & -0.93 & 0.98 & 0.99 & 0.99 & 0.99 & 0.99 \\
Total soluble solids & -0.99 & 0.96 & 0.98 & 0.96 & 0.99 & 0.98 \\
Total titratable acidity & 0.98 & -0.98 & -0.99 & -0.98 & -0.99 & -0.99 \\
\hline
\end{tabular}




\section{REFERENCES}

1. Pamplona-Roger GD Healthy Foods. Editorial Safeliz. Madrid, 2003.

2. USDA. Nutrient Database for standard reference, 2006. (http://www.thefruitpages.com/chartmango.shtml)(Accessed $7^{\text {th }}$ November, 2010).

3. FAOSTAT. Preliminary 2009 Data Now on Mango, FAO Rome, 2010. (http://faostat.fao.org/site/567/DesktopDefault.aspx?PageID=567\#ancor) (Accessed $7^{\text {th }}$ November, 2010).

4. FAOSTAT. FAO Statistics, Food and Agriculture Organization of the United Nations, Rome, Italy, 2007 (http://faostat.fao.org/) (Accessed 23 ${ }^{\text {rd }}$ May, 2010).

5. Temple L Le marche des fruits et legumes au Cameroun. Bulletin technique. CIRADIRAD (Ed). Yaounde, Cameroun,1999.

6. Litz RE The mango: Botany, Production and Uses. CAB International, Wallingford Oxon., UK, 1997.

7. Sauco V Mango production and world market: Current situation and future prospects. Acta Hort. 2004; 645: 107-116.

8. Mamiro P, Fweja L, Chove B, Kinabo J, George V and K Mtebe Physical and chemical characteristics of off-vine ripened mango (Mangifera indica L) fruit (Dodo). African J. of Biotechn. 2007; 6 (21): 2477-2483.

9. Rivera RA A Guide to Growing Organic Mango with Natural Farming System, 2009. (http:// www scribed. Com/doc/15766222/Guide to Growing organic-mango with natural farming-system) (Accessed $28^{\text {th }}$ November, 2010).

10. AOAC. Official Methods of Analysis. $15^{\text {th }} \mathrm{Ed}$, Association of Official Analytical Chemists, Arlington VA, 1990.

11. Ihekoronye AI and PO Ngoddy Integrated Food Science and Technology for the tropics. Macmillan Publishers Ltd, London, 1985.

12. Kays SJ Postharvest Physiology of Perishable Plant Products. Van Nostrand Reinhold, New York. p 2471991.

13. Favier JC, Ireland-Ripeit J, Luussuc $\mathbf{C}$ and $\mathbf{M}$ Feinberg Repertoire gener des aliments. Tome 3: Table de composition des fruits exotiques, fruits de cueillette d’Afrique. INRA (Ed), pp 55-59. 1993.

14. Gil A, Duarte I, Delgadillo I, Colquhoun I, Casuscelli F, Humpfer E and M Spraul Study of the compositional changes of mango during ripening by use of nuclear magnetic resonance spectroscopy. J. Agric. Food Chem. 2002; 48: 1524 1536. 
15. Vazquez-Salinas $\mathbf{C}$ and $\mathbf{S}$ Lakshminarayana Compositional changes in mango fruit during ripening at different storage temperatures. Journal of Food Science. 1985; 50: 1646-1648.

16. Mitra S and EA Baldwin Mango In: Postharvest physiology and storage of tropical and subtropical fruits. CAB International, New York, 1997.

17. Fuchs $\mathbf{Y}$, Pesis E and G Zauberman Changes in amylase activity, starch and sugar contents in mango fruit pulp. Sci. Hort., 1980; 13: 155-160

18. Jha SN, Chopra S and ARP Kingsly Determination of Sweetness of Intact Mango using Visual Spectral Analysis. Biosys.s Eng., 2005; 91 (2): 157-161.

19. Dadzie BK and J Orchard Routine Post Harvest Screening of Banana/Plantain Hybrids: Criteria and Methods. INIBAP Technical Guidelines 2, Wageningen, The Netherlands, p 63, 1997.

20. Aina JO Physico-chemical changes in African Mango (Irvingia gabogensis) during normal storage ripening. J. Food Chem., 1990; 36: 205 - 212.

21. Tovar B, Ibarra LI, Garcia HS and M Mata Some compositional changes in Kent mango (Mangifera indica) slices during storage. J. App. Hort.. 2000; 2 (1): 10-14.

22. Gale CR, Christopher NM, Paul DW and C Cyrus_Vitamin C and risk of death from stroke and coronary heart disease in cohort of elderly people. BMJ, 1995; 310 : 1563 (http://www.bmj.com/content/310/6994/1563.full)(Accessed $9^{\text {th }}$ December, 2010)

23. Szeto YT, Tomlinson B and IFF Benzie Total antioxidant and ascorbic acid content of fresh fruits and vegetables: implications for dietary planning and food preservation. Bri. J. of Nutr. 2002; 87: 55-59.

24. McClements DJ Analysis of Food Products. Food Science 581. 2003. (http://wwwunix.oit.umass.edu/ mcclemen/581Ash\&Minerals.html) (Accessed 23 ${ }^{\text {rd }}$ May, 2010)

25. Adeyemi OS and AT Oladiji Compositional changes in banana (Musa ssp.) fruits during ripening. Afric. J. of Biotechn. 2009; 8 (5): 858-859.

26. Ferrao JEM, Ferrao AMBC and AMG Anatures Garcia deorta, serieda estudes Agronom. 1987; 14 (1-3):35-39.

27. Institute of Medicine Food and Nutrition Board. Dietary Reference Intakes: Calcium, Phosphorus, Magnesium, Vitamin D and Fluoride. National Academy Press.

Washington, D.C., 1999.

28. Kader AA Perspective: Flavor quality of fruits and vegetables. Journal of the Science of Food and Agriculture J. Sci. Food Agric. 2008; 88:1863-1868. 


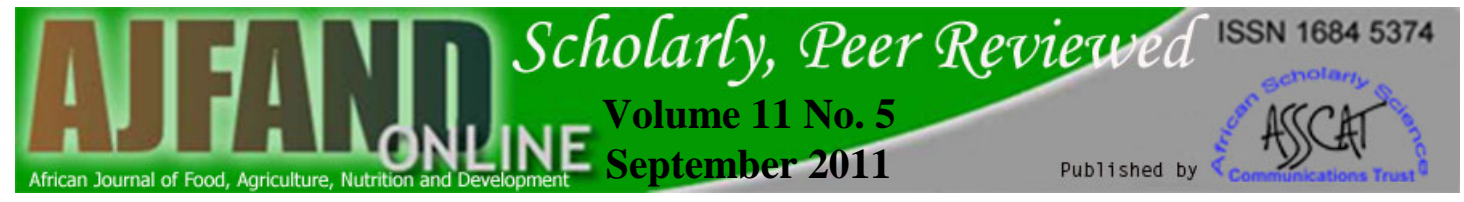

29. Bender RJ, Brecht JK, Baldwin EA and TMM Malundo Aroma Volatiles of Mature-green and Tree-ripe Tommy Atkins Mangoes after Controlled Atmosphere vs. Air Storage. 2000; HortSc. 35 (4):684-686.

30. Idsteom $\mathbf{H}$ and $\mathbf{P}$ Schreier Volatile constituents of alphonso mango (Mangifera indica). Phytochem. 1985; 24 (10): 2313-2316. 